\title{
El cementerio municipal de Soacha, Cundinamarca: ejemplo de un lugar patrimonial escenario de tensiones ${ }^{2}$
}

\footnotetext{
- Recepción: 30 de enero de 2021 - Evaluación: 07 de abril de 2021 - Aprobación: 16 de junio de 2021
}

\begin{abstract}
Resumen: El estudio de las prácticas funerarias expresadas a través del tiempo en un mismo territorio permite abordarlas desde una perspectiva patrimonial, en donde las tensiones que generan los comportamientos de diversos grupos frente a la muerte activan procesos de valoración y apropiación de un espacio que sintetiza, como pocos, la memoria histórica, las creencias religiosas y las transformaciones sociales de la población de Soacha (Cundinamarca). El cementerio municipal de Soacha, además de ser el escenario de tensiones, permite explorar las nuevas manifestaciones en torno a la muerte y la larga tradición indígena de este territorio, ocupado desde tiempos remotos de forma ininterrumpida por más de 10.000 años. El recorrido histórico, por lo tanto, permite llevar a cabo reflexiones desde el patrimonio cultural y la memoria de un territorio.
\end{abstract}

Palabras claves: tensiones, patrimonio, historia, memoria, muerte.

Para citar: Rivas Estrada, S. (2021). El cementerio municipal de Soacha, Cundinamarca: ejemplo de un lugar patrimonial escenario de tensiones. Perspectiva Geográfica, 26(2), 72-92. https://doi.org/10.19053/01233769.12429 


\title{
The municipal cemetery of Soacha, Cundinamarca: an example of a heritage site that is the scene of tensions
}

\begin{abstract}
The study of burial practices expressed over time in the same territory allows them to be approached from a heritage perspective, where the tensions generated by the behaviors of different groups in the face of death activate processes of valuation and appropriation of a space that synthesizes, as few others, the historical memory, religious beliefs and social transformations of the population of Soacha (Cundinamarca). The municipal cemetery of Soacha, besides being the scene of tensions, allows exploring the new manifestations around death and the long indigenous tradition of this territory, occupied since ancient times without interruption for more than 10,000 years. The historical journey, therefore, allows to carry out reflections from the cultural heritage and memory of a territory.
\end{abstract}

Keywords: tensions, heritage, history, memory, death.

\section{Cemitério municipal de Soacha, Cundinamarca: exemplo de um local patrimonial cenário de tensões}

\begin{abstract}
Resumo: O estudo das práticas funerárias expressas ao longo do tempo em um mesmo território permite abordá-las desde uma perspectiva patrimonial, onde as tensões geradas pelos comportamentos de diversos grupos diante à morte ativam processos de valorização e apropriação de um espaço que se sintetiza, como poucos, a memória histórica, as crenças religiosas e as transformações sociais da população de Soacha (Cundinamarca). O cemitério municipal de Soacha, além de ser o cenário de tensões, permite explorar as novas manifestações em torno à morte e a longa tradição indígena deste território, ocupado desde tempos remotos de forma ininterrupta por mais de 10.000 anos. O percurso histórico, portanto, permite realizar reflexões a partir do património cultural e a memória de um território.
\end{abstract}

Palavras-chave: tensões, patrimônio, história, memória, morte. 


\section{Introducción}

El patrimonio cultural ${ }^{3}$ existe como una fuerza política en la medida en que es recreado en conmemoraciones, monumentos y museos. Así pues, los monumentos más icónicos de una nación son los que recuerdan la fundación y los actores de la misma, visibles en lugares públicos de acceso masivo como las plazas principales, las iglesias y los cementerios (García Canclini, 1990).

El cementerio puede ser considerado como una institución que "resguarda el pasado y permite la expresión material de la memoria colectiva, que lo hace a partir de una lenta y permanente actualización" (Uvietta, 2015, p. 17). Sin embargo, estos lugares de la memoria, pese a su importancia dentro de la sociedad, se encuentran en un aparente peligro de desaparición. El primer factor de amenaza lo constituyen las difíciles condiciones de manutención, las cuales los llevan, en algunos casos, a procesos de abandono.

El segundo peligro se caracteriza por la desvalorización de estos espacios, los cuales contienen un acervo histórico de gran riqueza no oficial o contramemoria, como problematiza Losonczy (2001). En tercer lugar, encontramos que los prejuicios sociales tejidos en torno a estos (liminalidades), las políticas de la Iglesia Católica y las malas administraciones, sumados a la especulación inmobiliaria, son factores de deterioro de los camposantos que aumentan las posibilidades de su destrucción.

En cuarto lugar, vemos que el crecimiento urbano descontrolado de las ciudades ha arrinconado la mayoría de los cementerios del siglo XIX y Xx, limitando su desarrollo y fortaleciendo su invisibilización. Finalmente, y quizás más importante, está el cambio en las prácticas funerarias por parte de la sociedad actual, la cual ha encontrado en la incineración de los

3 El patrimonio, en palabras de Josep Ballart, alimenta en el ser humano una sensación reconfortante de continuidad temporal e identitaria al estar vinculada con una tradición. En las sociedades contemporáneas estos sentimientos están presentes, de la misma forma que en el pasado, a tal punto que son necesarios tanto en el presente como antes (Ballart, 1997). restos una salida práctica y más económica para darle tramite a la muerte de sus miembros, evitando así el desarrollo de inhumaciones o disposición del cuerpo en bóvedas sobre tierra, lo cual evita, a su vez, el proceso de descomposición.

Los cementerios sintetizan en su arquitectura, su simbolismo y su distribución espacial las costumbres y manifestaciones funerarias de las poblaciones occidentales, razón por la cual también son un lugar de la memoria colectiva e individual, susceptibles de ser leídos y analizados como un documento histórico y social, de allí que se piense en estos espacios como los ideales para conocer los aspectos más complejos de la cultura (Villa Posse, 1993; Ferro, 2009). Su evolución y sus trayectorias se pueden relacionar con las diferentes épocas de transformación que experimentan las sociedades, por lo cual estos lugares no solo pueden ser percibidos e idealizados con el fin de rendirle culto a los muertos, sino que también tienen la potencia de revelar la historia y las creencias de la población que los crea, habita y transforma.

La puesta en valor de los cementerios como patrimonio contribuye a reactivar procesos de memoria ${ }^{4} \mathrm{e}$ identidad colectiva. El cementerio como territorio de la memoria está inserto en el acto de recordar, el cual se desarrolla de manera individual, pero, a su vez, se inscribe en procesos colectivos (Santos Moreno, 2013). En este orden de ideas, el cementerio puede ser interpretado como un lugar de la memoria (Nora, 1996), como espacio de rememoración con un valor simbólico particular y con fuertes recreaciones del contexto sociopolítico (Moranense, 2009). De igual forma, es un lugar de gran valor ya que en él se expresan múltiples relaciones sociales, y permite darle continuidad a las relaciones que cambian de estado al ser truncadas por la muerte.

\footnotetext{
4 La memoria, entendida como sustenta Ricoeur (2008), alude a "un fenómeno colectivo y social que nace del acto testimonial de un pasado que penetra porque hace parte del presente, que es simple y está en constante metamorfosis, por eso divide" (citado en Lamilla, 2011, p. 191).
} 
Desde una perspectiva más amplia, el cementerio también es un espacio de negociación (Ferro, 1999), en donde lo tradicional entra en tensión con lo popular. Las comunidades religiosas y la sociedad, a través del desarrollo del ritual funerario, establecen una serie de pasos, los cuales dan un orden a la ceremonia y permiten cerrar el ciclo de la vida y preparar al difunto para el juicio final (bajo la fe católica). Sin embargo, los dolientes, en muchos casos, enriquecen las manifestaciones religiosas con sus formas particulares de expresar el duelo, vinculando lo sagrado con lo profano, lo religioso con lo secular, generando con ello un dinamismo en la práctica religiosa que permite la supervivencia del lugar, que, a la vez, genera tensiones entre los actores.

El cementerio de Soacha se encuentra ligado no solo a su pasado reciente, también a la muy larga historia de ocupación prehispánica, la cual se encuentra reflejada al interior de esta necrópolis bajo diferentes aspectos. La historia del cementerio se encuentra enriquecida por una gran diversidad de tradiciones y de formas de expresar y sentir la muerte, las cuales encuentran su sustrato en su pasado indígena, transformado por la colonia, la república y la modernidad.

\section{Ubicación geográfica del área del estudio}

El municipio de Soacha (Cundinamarca) se encuentra ubicado al sur de la Sabana de Bogotá (Figura 1), una formación natural que hace parte de tres planicies del gran paisaje de conforma el altiplano cundiboyacense, el cual descansa sobre la cordillera Oriental, una de las tres ramificaciones de la cadena montañosa de los Andes (Rodríguez, 2017). La extensión actual de este municipio colombiano es de $184,45 \mathrm{~km}^{2}$, de la cual tan solo el área urbana cubre una superficie de 19 km², zona en la que se concentra la mayor parte de la población.

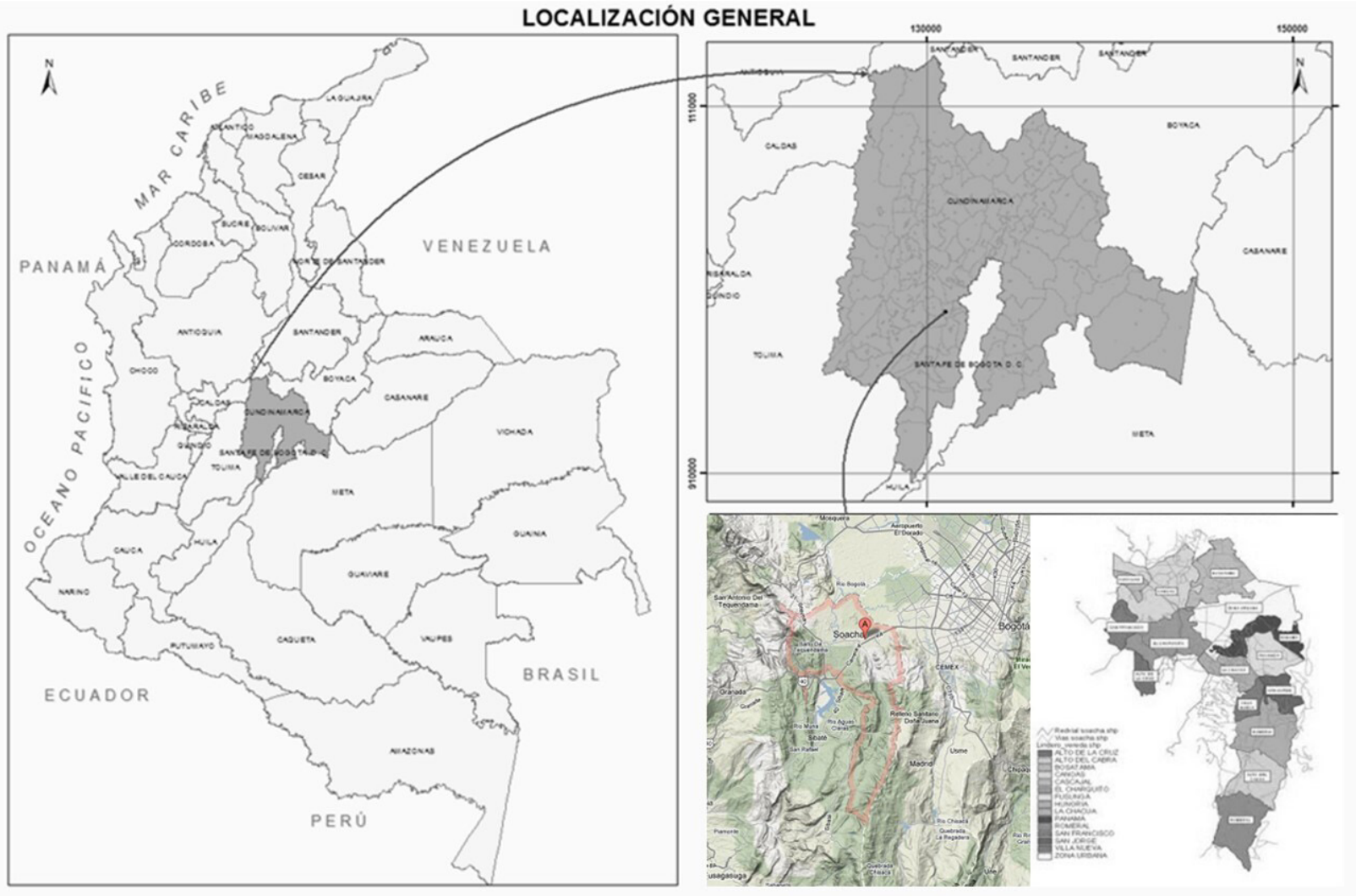

FIGURA 1. Ubicación geográfica del área de estudio

FUENTE: elaboración propia (2021). 


\section{Metodología}

Para el desarrollo de la investigación se trabajó en dos frentes principales: el primero, enfocado en la recopilación, el análisis y la sistematización de información primaria y secundaria, historiográfica, cartográfica y gráfica del cementerio y el territorio de Soacha, con el fin de encontrar evidencias que permitieran identificar transformaciones en las prácticas funerarias a lo largo de la trayectoria histórica de las comunidades que ocuparon y habitan esta zona geográfica. El segundo se caracterizó por hacer uso del método etnográfico como fuente de información sobre el desarrollo de prácticas al interior del cementerio por parte de sus usuarios. En este sentido, se realizaron entrevistas abiertas y a profundidad tanto a visitantes del camposanto como a empleados del lugar, con el fin de tener diversas miradas sobre este sitio.

\section{Formas de enterrar y ser enterrado: tradiciones prehispánicas en tensión}

El desarrollo de los rituales religiosos en torno a la muerte por parte de las sociedades precolombinas fue uno de los temas que más llamó la atención de los primeros cronistas y exploradores en el Nuevo Mundo. La muerte de algún líder indígena fue materia de extensos relatos, sin embargo, lo que en un principio generó curiosidad fue motivo de tensión entre dos formas de entender lo sagrado.

La vida y la muerte eran entendidas de formas antagónicas por los españoles y los indígenas, lo cual creó tensiones entre unos y otros y generó el desarrollo de sincretismos religiosos observables en un inmenso y complejo palimpsesto funerario. Las comunidades prehispánicas que habitaron la Sabana de Bogotá, al igual que otras sociedades indígenas nativas, se caracterizaron por llevar una relación muy estrecha entre la vida y la muerte, en parte porque esta no se percibía como un hecho ajeno de la cotidianidad, testimonio de un complejo sistema de pensamiento dualista en donde se encontraba arraigada la idea de la existencia de dos casas o mundos. La casa de arriba, cálida e iluminada, les correspondía a los vivos. La casa de abajo, destinada para los muertos, era fría y oscura (Colón, 2004; Reichel-Dolmatoff, 1990).

El territorio de Soacha, al igual de todos los asentamientos prehispánicos registrados durante más de setenta años de investigación arqueológica en la Sabana de Bogotá, da cuenta de una indisoluble relación entre el espacio ocupado por los vivos y por los muertos, un territorio memoria en donde los ancestros se encuentran siempre presentes. En otras palabras, la arqueología nos muestra que las poblaciones indígenas compartían sus espacios comunales y habitacionales con sus muertos, hecho que al parecer generaba un arraigo mayor en el territorio y facilitaba la comunión con los antepasados.

Los primeros habitantes de la Sabana de Bogotá llevaron a cabo enterramientos humanos bajo tierra, sin evidencias de monumentalidad funeraria. Los contextos mortuorios más antiguos de la zona corresponden al yacimiento de los abrigos rocosos en los sitios El Tequendama I y II (Correal \& Van der Hammen, 1977; Correal Urrego, 1979, 2001; Hurt et al., 1977), datados entre los 13.000 y 2.500 AP ${ }^{5}$; Sueva (Cárdenas Arroyo, 2002; Correal Urrego, 2001) y Galindo (Bojacá, Cundinamarca), datados entre 8.745 y 5.000 AP (Pinto, 2003); Checua (Nemocón, Gundinamarca), con antigüedades entre el 8.500 y 3.000 AP (Groot, 1992), y Aguazuque (Soacha, Gundinamarca), datado entre el 5.025+/-40 AP y 2.725+/-35 AP (Correal Urrego, 1990). Estos yacimientos revelan el desarrollo de un patrón funerario que consistió en el enterramiento de personas adultas en posición decúbito lateral y decúbito dorsal con los miembros flexionados (posición fetal), mientras que los infantes recibían un

5 La sigla AP traduce literalmente antes del presente y es usada en la literatura arqueológica y geológica para referirse a un periodo concreto de la historia. Sin embargo, por norma, debe hacerse la resta en años a partir de 1950 como el año en el que se establecieron las curvas de calibración de radiocarbono. 
tratamiento diferencial y eran sepultados en posición de cuclillas.

Con respecto al lugar en donde se llevaron a cabo las inhumaciones, se ha establecido que fueron en los mismos entornos habitacionales, ya fuera abrigos rocosos o campamentos a cielo abierto, lo que supone una muy temprana relación de comunicación y quizás de veneración de los muertos por parte de estos grupos indígenas.

En todos los casos, las ofrendas funerarias estaban compuestas por artefactos de hueso y roca, los cuales estaban cargados de simbolismos que buscaban preparar y dotar a los individuos para el tránsito a una nueva vida o existencia en un plano espiritual. De acuerdo con las hipótesis, como parte de los rituales funerarios desarrollados en el sitio Aguazuque se llevaron a cabo prácticas de canibalismo, situación que probablemente generó tensiones entre los grupos nómadas de este horizonte cultural, ya que no se volvió a evidenciar tal comportamiento en el registro arqueológico.

Con el desarrollo de asentamientos permanentes por parte de comunidades agrícolas entre el 1000 a. C. y el 800 a. C. se observaron cambios en las formas de enterramiento y se registra una amplia variabilidad en el desarrollo de las prácticas funerarias. Un aspecto fundamental observado en las excavaciones arqueológicas en sitios asociados a comunidades agrícolas consiste en que en las mismas áreas donde se ha registrado el hallazgo de tumbas también han sido registradas vivienda de planta circular (un bohío) y rectangular, lo cual indica que, desde dicha época, se estructuró una compleja relación entre los vivos y los muertos.

En el sitio Nueva Esperanza (Soacha, Cundinamarca), hasta el momento se han registrado más de 2.000 tumbas a lo largo de las excavaciones arqueológicas (Figura 2), así como decenas de plantas de vivienda de forma circular, ovalada y rectangular. La secuencia temporal de Nueva Esperanza se remonta al 400 a. C. y se prolongó hasta por lo menos el año de 1500 d. C. (González, 2016; Romano, 2016; Calderón \& Rivas, 2017; Calderón et al., 2019; Rivas, 2020). En esta aldea se logró observar cómo, durante toda la secuencia de ocupación, la comunidad prehispánica convivió con sus muertos y llevó a cabo sus inhumaciones al interior y en los alrededores de las viviendas.

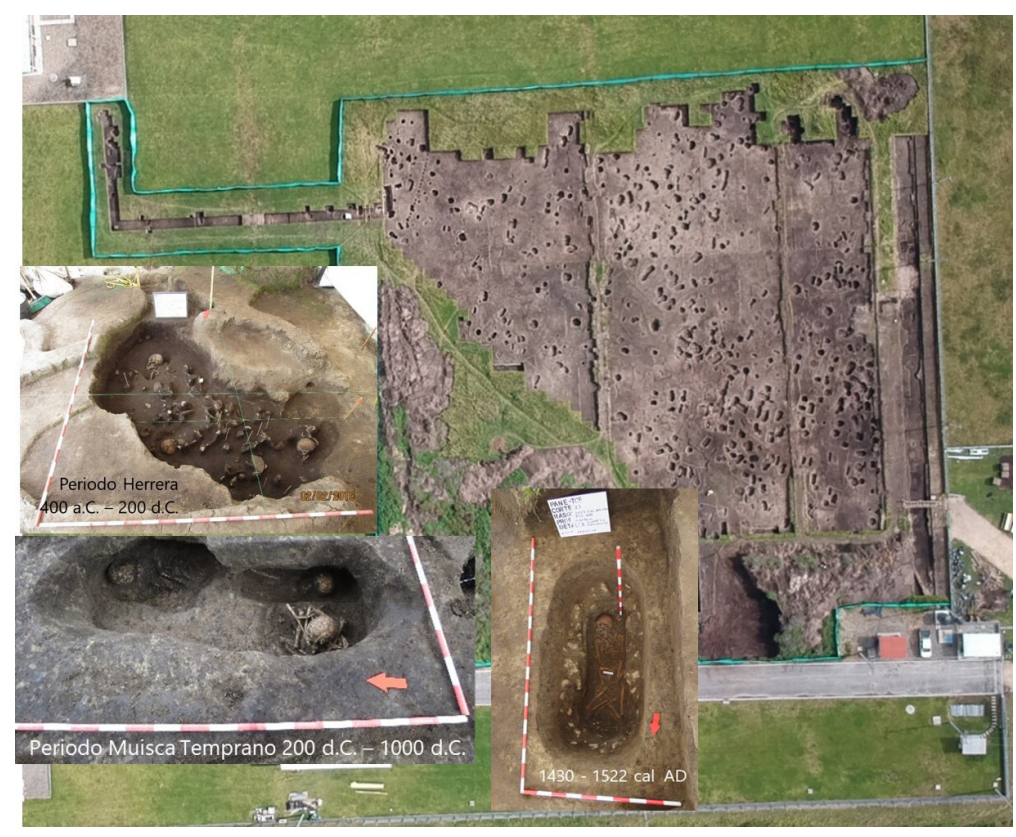

FIGURA 2. Contexto funerario prehispánico asociado al periodo cultural Herrera (400 a. C. -

200 d. C.) en el sitio arqueológico Nueva Esperanza

FUENTE: Rivas (2020). 
Patrones semejantes se han identificado en otros yacimientos arqueológicos como Portalegre (Soacha, Cundinamarca), en donde se excavaron 130 tumbas con forma rectangular y siete estructuras habitacionales datadas entre el 1035+/-1 15 d. C. y el 1230+/110 a. C. ${ }^{6}$ (Botiva, 1989; Boada, 2000, pp. 22-25).

A finales de los ochenta, en el sitio arqueológico Candelaria La Nueva, ubicado cerca al río Tunjuelito, también se identificaron unidades de vivienda y áreas de enterramiento humano datadas entre el $1175+/-110$ d. C. y 1250+/-110 d. C., aunque se presume que la ocupación del sitio se prolongó hasta el periodo de "contacto" (1537 d. C.), ya que en una de las tumbas fueron halladas cuentas de vidrio de origen europeo (Boada, 2000, p. 36).

Al igual que en Soacha Portalegre, en el sitio de Candelaria La Nueva se puede observar que las formas de las estructuras funerarias y las posiciones de los cuerpos son similares y que la cercanía de estas con las unidades de vivienda es significativa. El estudio desarrollado por Leguizamón (2016) tomó como casos de estudio los sitios anteriormente descritos con el fin de determinar si existía una relación entre las unidades de vivienda y las tumbas prehispánicas y encontró que, para el caso de las comunidades "muiscas" estudiadas, es altamente significativo.

En el sitio arqueológico de Tibanica, ubicado en los límites de Soacha y Bosa, las excavaciones arqueológicas permitieron identificar cerca de 13 plantas de vivienda y 600 tumbas (Langebaek, 2012; Langebaek et al., 2011; Langebaek et al., 2015) en las que se hallaron 743 individuos (Langebaek et al., 2015). Las fechas de radiocarbono fueron obtenidas de tres tumbas y registraron antigüedades de 920+/-40 d. C.; $1180+/-40$ d. C. y 1350+/-40 d. C. Langebaek y su equipo, a partir de esta investigación, dan cuenta del mismo patrón identificado en los sitios arqueológicos descritos anteriormente, y es el de la relación entre

6 Fechas sin calibrar las unidades de vivienda y las tumbas de los antiguos habitantes de estas aldeas.

Para los grupos indígenas que habitaron la Sabana de Bogotá, la cercanía física con sus muertos era fundamental, ya que conservaban viva la memoria y los lazos de comunicación con los ancestros no se rompían. De hecho, los muertos jugaban un papel muy importante en el mundo político de estas sociedades, al ser concebidos como consejeros en los momentos cruciales de toma de decisiones, así como figuras importantes que guiaban a los guerreros en los enfrentamientos con otras poblaciones (Jiménez de Quesada, s. f.).

Es claro que durante el periodo prehispánico se experimentaron múltiples formas de inhumación. A lo largo de la secuencia cultural, las comunidades precolombinas retomaron tradiciones de sus ancestros e incorporaban nuevos tratamientos, los cuales fueron paulatinos o graduales. Solo un aspecto se mantuvo casi sin alteraciones por más de 10.000 años: la realización de los enterramientos cerca de la vivienda, hecho que, como se explorará en el siguiente apartado, se vio completamente transgredido.

\section{Las tensiones en la época colonial entre el rito católico y el indígena}

Como pueblo de indios bajo el régimen colonial, Suacha (como antiguamente se llamaba) fue fundada en 1600 por el oidor de la Real Audiencia y visitador Luis Enriquez (Cancino, 1940; Rodríguez, 2017). Ese mismo año, se encarga la construcción de dos capillas doctrineras (una en el pueblo de Bosa y la otra en Soacha) consagradas a San Bernardino de Siena, apóstol y predicador de la Orden Franciscana (Figura 3).

Por otra parte, la construcción de un tempo doctrinero implicó una serie de cambios en las prácticas religiosas de los indígenas que habitaban la zona. 
Tradicionalmente llamados "muiscas", los habitantes del altiplano cundiboyacense acumulaban una larga trayectoria de ocupación humana de la Sabana de Bogotá. Cronistas como De Simón, Aguado y Castellanos los describen como una sociedad muy religiosa en la que ciertos individuos tenían por misión servir de puente entre el mundo de los dioses y el terrenal. Estos jeques, como los llamaron los europeos, también estaban encargados de presidir las ceremonias fúnebres de los miembros de la comunidad.
Paralelamente, se inicia la conformación de la traza urbana del pueblo de indios de forma ortogonal (Rodríguez, 2017) siguiendo los cánones de la época colonial, que buscaba ordenar los espacios y el territorio que consideran salvaje. Las huellas de la conformación de ese primer trazado urbano aún perviven en el centro histórico de la población (Figura 4), y si bien la mayoría de las construcciones del periodo colonial desaparecieron durante procesos de renovación urbana, un sector que rodea la plaza central conserva vestigios de aquella arquitectura.

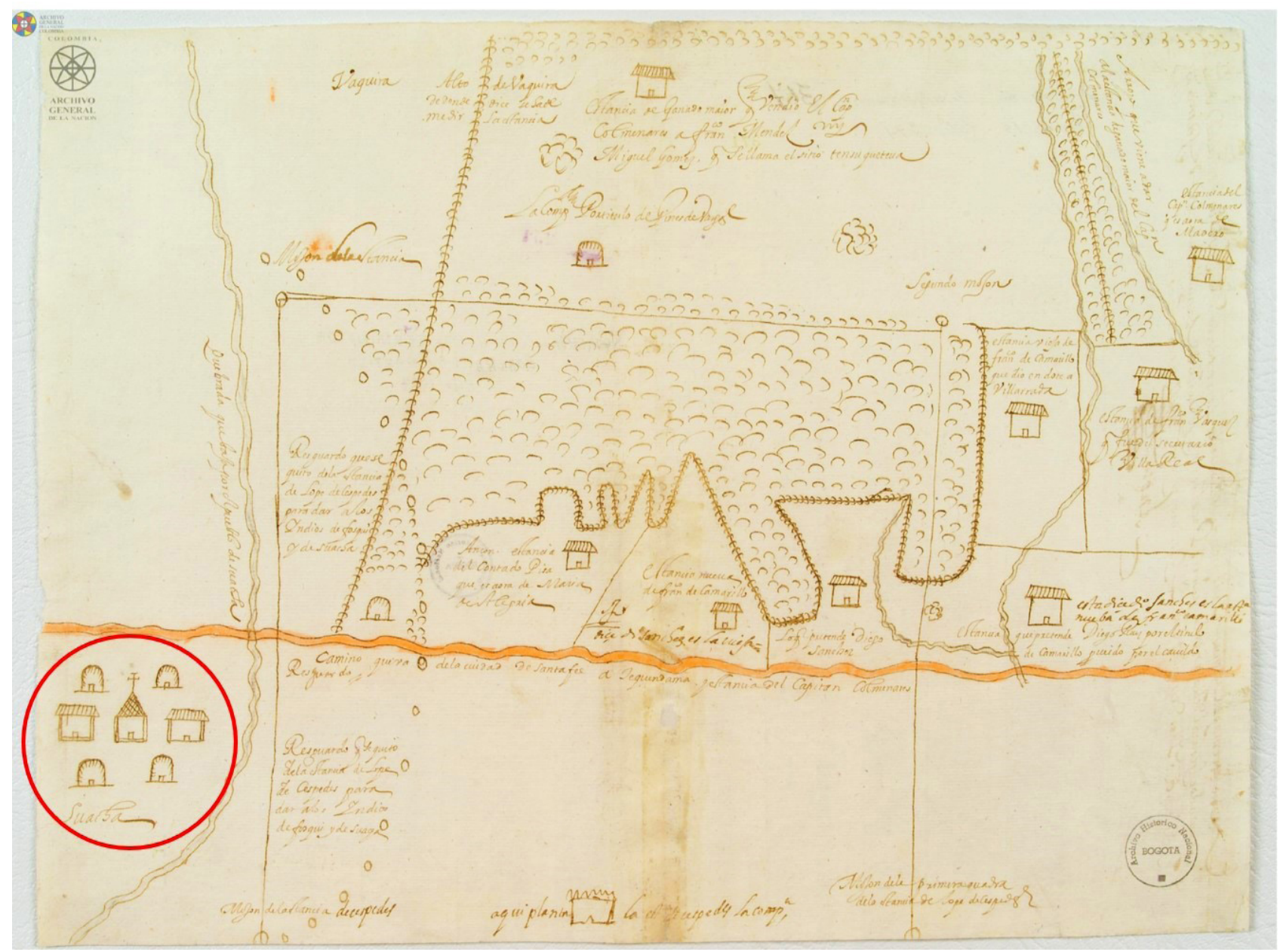

FIGURA 3. Mapa del siglo XVI en el que se aprecia la ubicación del pueblo de Soacha: la visión teocéntrica muestra la capilla doctrinera de San Bernardino de Siena en el centro de la población

FUENTE: Archivo General de la Nación (AGN), Sección Mapas y Planos, Mapoteca n 4, ref. 443A. Dimensiones: 31 $\times 41 \mathrm{~cm}$. Modificado por el autor. 


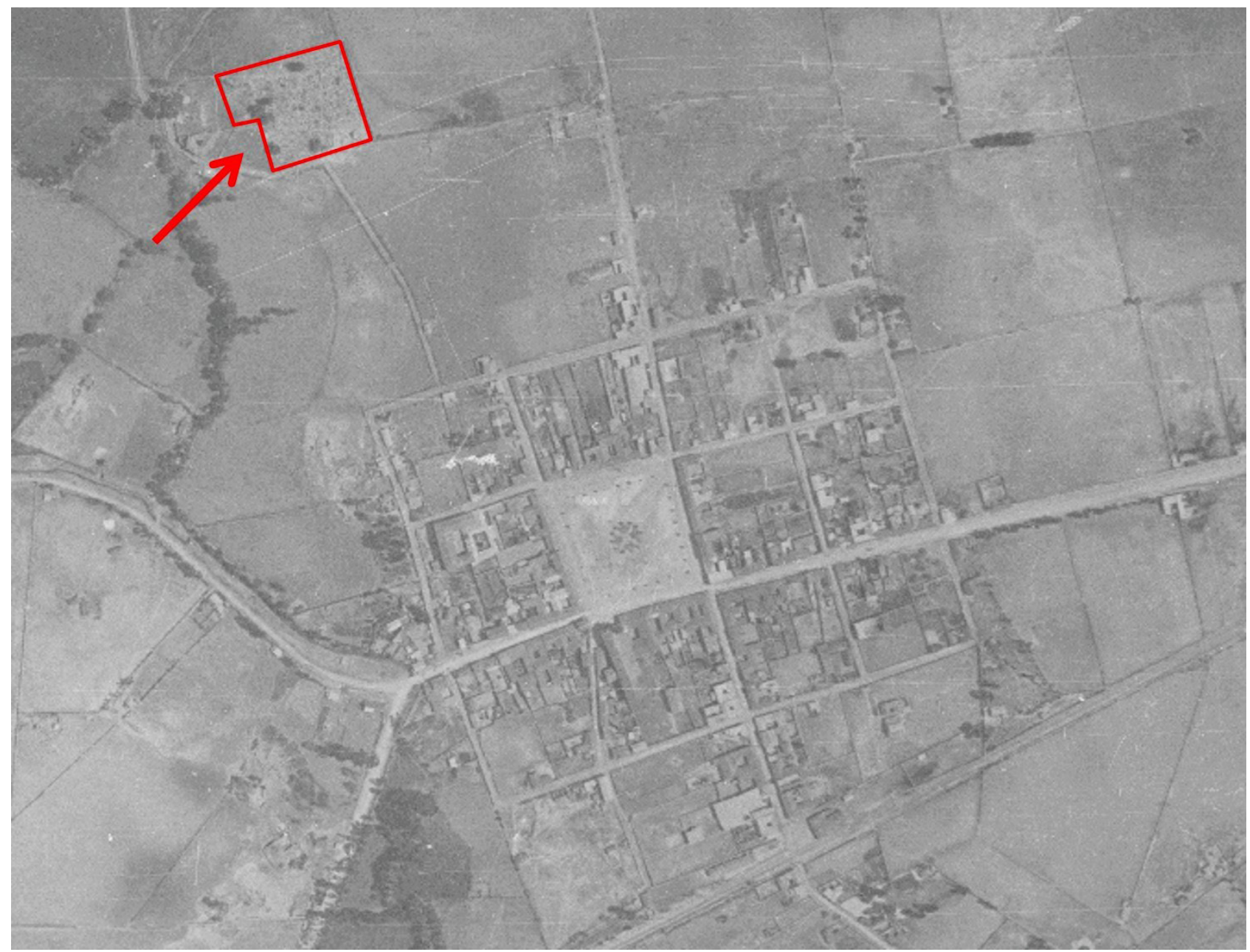

FIGURA 4. Aerofotografía de Soacha, 1940: en la parte superior, en rojo, se muestra la ubicación del cementerio y la conformación de su traza

FUENTE: Instituto Geográfico Agustín Codazzi (IGAC), vuelo A197. Modificado por el autor.

En el año de 1759, luego de la visita del oidor Joaquin Arostagui y Escoto, se contabilizan 332 indios adultos y su población total no sobrepasaba las 430 personas. El Real Mandato de 3 de agosto de 1774 ordenó la reducción de los pueblos de indios cuya población había declinado drásticamente para trasladarla a otros y así también liberar tierras para la venta y beneficio de la Corona española, hecho que generó que en 1775 se realizara el traslado de los indígenas de Usaquén al pueblo de indios de Soacha (Riaño, 2016). En esa misma época y en otras posteriores es posible que indios de otros resguardos fueran trasladados bajo las mismas premisas, las cuales obedecieron a la disminución de la población en estos territorios y su inviabilidad para sostener las iglesias.
Sin embargo, es posible que las causas reales fueran la necesidad de otorgar títulos de propiedad de tierras a un número creciente de hombres españoles y criollos y conformar más parroquias que, en otras palabras, eran pueblos de blancos (Riaño, 2016).

Durante el régimen colonial, las tradiciones funerarias de las poblaciones indígenas comenzaron a cambiar lentamente, pero a la fuerza, para adaptarse a los cánones impuestos por la Iglesia católica. Las tensiones experimentadas entre los actores de la época se trasladan al campo de las creencias religiosas de ambas partes.

El enterramiento de los miembros de la población al interior o alrededor de las viviendas, al ir en contra 
del dogma católico, además de restarle control a la Iglesia en el desarrollo de este rito de paso, generaron muchas más tensiones entre los indígenas, el clero y la sociedad civil europea, la cual se caracterizaba por su visión dogmática del mundo.

No obstante, estos cambios en las expresiones funerarias conllevaron el desarrollo de un sincretismo religioso que hoy pervive en los pobladores de Soacha. El desarrollo de funerales acompañados con música y consumo de comida y bebida es uno de estos elementos del pasado que han perdurado en el tiempo con algunas variaciones.

Si bien las prácticas funerarias de las poblaciones nativas amerindias se vieron transformadas a partir del contacto con los europeos y la dominación de estos durante el periodo colonial, el desarrollo de los enterramientos al interior y en los alrededores de las iglesias era visto como la forma más digna, religiosa, lógica y segura para sepultar a los muertos católicos, ya que aseguraba la salvación de las almas después de pagar las indulgencias. Este cambio generó tensiones entre los nativos indígenas y la institución eclesiástica, ya que se rompieron de forma abrupta las tradiciones prehispánicas de inhumar a los muertos al interior de las aldeas indígenas.

La historia de Juanico, un niño indio muerto aproximadamente entre 1571-1572, bautizado por orden del psihipqua del pueblo de Tota y del encomendero Diego Montañez con el nombre de don Diego de Torre, ilustra las tensiones y resistencias de los "muiscas" frente al desarrollo de los enterramientos en las iglesias católicas: "el niño fue enterrado en la puerta de la iglesia de los aposentos del encomendero" (AGN, E21, ff 513 - 515v, citado en Gamboa, 2013, p. 454), y más adelante se encuentra otra anotación al respecto, en donde el encomendero da la orden "de sepultarlo en la iglesia contra la voluntad de su familia, porque Juanico ya era cristiano" (p. 455).

Durante el periodo colonial los cementerios fueron objeto de dominación absoluta por parte del clero católico y Soacha no debió ser ajena a esta realidad, por ello al interior de su iglesia y del atrio se deben encontrar las sepulturas de hombres, mujeres y niños (mayores de 7 años) convertidos a la fe cristiana. Las evidencias arqueológicas (Rivera, 2006) demuestran que, dependiendo de la ubicación de la inhumación en la iglesia, se puede interpretar cuál era la posición social del individuo en vida, comenzando con el altar o capillas anexas para las personas más pudientes hasta llegar al atrio como lugar destinado para los más pobres. Esta situación también puede interpretarse como un nuevo factor de tensiones, ya que los costos de los enterramientos en las iglesias se elevaban según su ubicación al interior de estas, además de que existían áreas de uso exclusivo para los miembros de las congregaciones religiosas.

El primer cementerio de Soacha no se encontraba en los extramuros, sino en el centro del poblado, justo en el atrio de la iglesia principal. Enterrar a los muertos en un lugar sacro (como la iglesia o alrededor de esta) era el canon de la época, pero en virtud de la promulgación de las leyes de sanidad se dio paso, tardíamente, a la conformación del actual cementerio municipal de Soacha.

\section{Los cementerios extramuros: nuevas tensiones para un viejo problema}

La construcción de cementerios en Europa y América se generó a partir de las reformas borbónicas promulgadas por Carlos III a finales del siglo XVIII con la Real Orden del 24 de marzo de 1781 y la Real Cédula del 3 de abril de 1787 y dieron lugar a la transformación de las tradiciones funerarias de dos continentes, lo que implicó un cambio radical de las prácticas de enterramiento en Occidente (Escovar, 2002; Rodríguez, 1999).

Durante el periodo colonial, el intercambio cultural entre indígenas y colonos europeos generó una 
serie de transformaciones en los rituales funerarios que se fueron asimilando por parte de los actores sociales de entonces (Rivera, 2006), quienes asumían una serie de comportamientos y pensamientos frente al hecho de morir. Los ritos religiosos en las ceremonias fúnebres se adelantaban en espacios sacralizados como iglesias y conventos, otorgándole a la Iglesia católica el empoderamiento necesario para manipular los eventos más importantes de la vida durante la colonia: nacimiento, adolescencia, madurez, agonía y muerte.

En Europa, la orden de construir camposantos alejados de las ciudades y villas buscaba poner fin a las epidemias que azotaban a la población europea y se convirtió en la solución a un problema de grandes magnitudes, ya que para la década de 1780 las iglesias estaban atiborradas de cuerpos en descomposición a causa de la epidemia de viruela que azotó al Nuevo Reino de Granada en 1782. En la segunda epidemia de esta enfermedad, entre 1801 y 1802, se vio la necesidad de realizar inhumaciones de los muertos por este mal en el cementerio del hospital San Juan de Dios o en el solar adyacente del hospital provisional de Las Aguas (Rodríguez, 1999).

Si bien la resistencia de la sociedad española a hacer uso del cementerio se prolongó por lo menos durante 28 años, en América, y en especial en el entonces Nuevo Reino de Granada que luego pasó a ser República de la Nueva Granada, la construcción y puesta en uso del cementerio de Bogotá se prolongó hasta 1832 (fecha en que se comenzó a sepultar a los individuos pobres) y 1836 (año en que se abrió definitivamente para que toda la sociedad lo usara), o sea, 55 años más tarde de emitirse la orden.

Las razones para que la población se resistiera a cambiar sus tradiciones de enterramiento se basaron en tres premisas: 1) los muertos de los ricos no podían mezclarse con los pobres, 2) el espacio ocupado por el cementerio se consideraba indigno y profano y 3) finalmente, pero más importante, se basaban en la idea de "resurrección de la carne", la cual permeó el cristianismo desde mucho antes de su conformación, es decir, es un pensamiento que puede remontarse al 164 a. C. (Blanco, 2010).

Estos ideales, sumados a la creencia en una sacralidad del cuerpo y de hacerlo en suelo sagrado, frente al trono de Dios, fueron las razones por las cuales las elites y los sacerdotes continuaron desarrollando inhumaciones en las iglesias, en contravención del artículo 346 de la Ley $1^{a}$ de 1827, generando, de esta manera, ganancias que permitían el mantenimiento de los templos católicos y perpetuando, en la medida de lo posible, el modelo colonial (1931, citado en Escovar \& Mariño von Hildebrand, 2007).

Sin embargo, estas tradiciones fueron duramente atacadas por las políticas públicas de la época y evitar la inhumación en el cementerio se hizo cada vez más dificil. Una estrategia para incentivar el uso del cementerio fue otorgarle a la Iglesia católica la administración de estos lugares hacia 1856, por un periodo de tiempo corto (aproximadamente seis años), cuando fue nuevamente levantado por cuenta de las políticas de desamortización de manos muertas instauradas por Tomás Cipriano de Mosquera. Si bien el impacto de esta orden se sintió con mayor fuerza en la capital de la república, es posible que en la periferia sus efectos no fueran tan drásticos.

Una vez superado el periodo de transición que supuso el cambio en las tradiciones funerarias, y la aceptación de uso del cementerio se instituyera, los ciudadanos acaudalados lograron marcar su territorio construyendo áreas exclusivas para la inhumación de sus muertos en una forma que les permitiera recuperar su dignidad y proyectar hacia la sociedad el estatus que ostentaban en vida.

Durante este periodo se experimentaron tensiones entre la Iglesia católica, la sociedad civil y la monarquía. La insistencia de las autoridades en realizar inhumaciones de los fallecidos a causa de la viruela era burlada frecuentemente por las familias acaudaladas con el beneplácito de sacerdotes, quienes facilitaban 
el desarrollo de los enterramientos al interior de las iglesias o conventos (Rodríguez, 1999).

Una vez superada la crisis sanitaria, la resistencia de la sociedad santafereña y, al parecer, de las poblaciones más pequeñas para realizar las exequias en los cementerios fue notoria. La persistencia en la creencia de que el ser inhumado al interior de los recintos sagrados generaba una protección para el alma y aseguraba la salvación motivó tal resistencia. En este sentido, las creencias en torno a la muerte fueron, por lo tanto, determinantes para la utilización de los cementerios extramuros.

Los primeros cementerios, al tener una connotación popular, generaron opiniones radicales por cuenta de las familias de mayor solvencia económica, lo que provocó en el año de 1822 la solicitud a las autoridades de disponer de un nuevo terreno para la construcción de un cementerio acorde con la condición social de las elites (Escovar \& Mariño von Hildebrand, 2007). De esta forma, se trató de generar una separación de clases sociales y estructurar la muerte al igual que la vida. Las tensiones entre la Iglesia y estos espacios a campo abierto y en los extramuros radicó básicamente en el temor a la pérdida de control que ejercía el clero en temas como la muerte.

Las familias acaudaladas llevaron a cabo la construcción de mausoleos acordes con su condición social en los cementerios y reflejaron en ellos su estatus y su abolengo. Esto generó nuevas tensiones entre "ricos" y "pobres", pues además de impulsar una monumentalidad funeraria dotada de prestigio con el uso de materias primas importadas, como el mármol de Carrara, y elaborada por los talleres más afamados de Europa, se abrió paso al uso de una iconografía cargada de simbolismos que solo la elite ilustrada podría descifrar. De igual forma, comenzaron a realizarse representaciones de escenas de la Biblia antes solo vistas en pinturas.

Una vez institucionalizados los cementerios extramuros como espacios dignos para sepultar a los miembros de la alta sociedad, se generaron nuevas tensiones entre los usuarios. Sin embargo, con la recuperación del control de la Iglesia en estos territorios, y nuevamente de la muerte, se reestructuraron las relaciones sociales y se asimiló una nueva "realidad".

\section{Tensiones en el cementerio municipal de Soacha}

El cementerio municipal de Soacha se encuentra ubicado al nororiente de este municipio de Cundinamarca (Colombia), a orillas del río Soacha, en lo que antiguamente eran los extramuros del pueblo (Figura 5). La construcción del cementerio se remonta posiblemente a 1894 (Cancino, 1940), año que también se encuentra grabado en uno de los bloques de la portada del camposanto (Figura 6). Sus dimensiones son de aproximadamente 9.795,15 m² y se registran más de 5.000 construcciones funerarias.

En su interior se pueden observar varias etapas de construcción. Una primera capa histórica del cementerio (entre 1894 y 1940) nos muestra la distribución espacial de las tumbas que se asemeja a la organización y distribución espacial de las viviendas de Soacha, girando alrededor de la plaza principal en medio de una vida rural, la misma que había tenido desde sus inicios. Esta dinámica se reflejaba en el cementerio, el cual presentaba una distribución espaciosa de sus tumbas: amplias áreas verdes conformadas por pastos y arboles hacían parte del camposanto. De igual forma, en el centro del cementerio se dibujaba una plazoleta en la cual se oficiaban los últimos actos litúrgicos para los recién fallecidos.

En 1914, el presbítero Alejandro Almonacid, quien tenía a cargo la parroquia de San Bernardino de Soacha, muere, al parecer, por causas naturales. Este personaje, del que poco se sabe en la actualidad, fue sepultado en el cementerio municipal de Soacha en un lugar privilegiado, en una de las esquinas del área central del cementerio y en su honor erigen una magnífica pira funeraria coronada con una cruz, elaborada en finos materiales como mármol y roca. También 
se observan tallas de gran factura, una de ellas en un altorrelieve que dibuja el rostro del presbítero. En esta construcción también se aprecia el manejo de símbolos religiosos que dan cuenta de sus dignidades, un anagrama con las iniciales de su nombre, y finalmente una dedicatoria de parte de sus hermanos. Pero, más allá de esto, podemos encontrar que la posición de esta tumba refleja la posición de la iglesia de San Bernardino de Soacha en el cementerio. Un símil del mundo de los vivos en el interior de la necrópolis.

Las aerofotografias y levantamientos planimétricos de los años 1940, 1958, 1970, 2000 y 2017 evidencian un crecimiento urbanístico del municipio que se va acrecentando a medida que pasa el tiempo. En principio se aprecia un crecimiento urbano ordenando que respeta la traza original, pero luego, a partir de los setenta, una ocupación del espacio desproporcionada y desordenada se registra en varias áreas, en zonas que antes eran cultivos, pastizales para ganadería o humedales. Estos procesos terminaron por reflejarse en el cementerio. Al observar el interior del cementerio, las inhumaciones más tempranas de las cuales se tiene registro corresponden a Bonifacio Montoya (1887) y Agapito Mesa (1888) y se caracterizan por su modestia, ya que fueron talladas en piedra arenisca de la que sobresale una cruz latina (Figura 7).
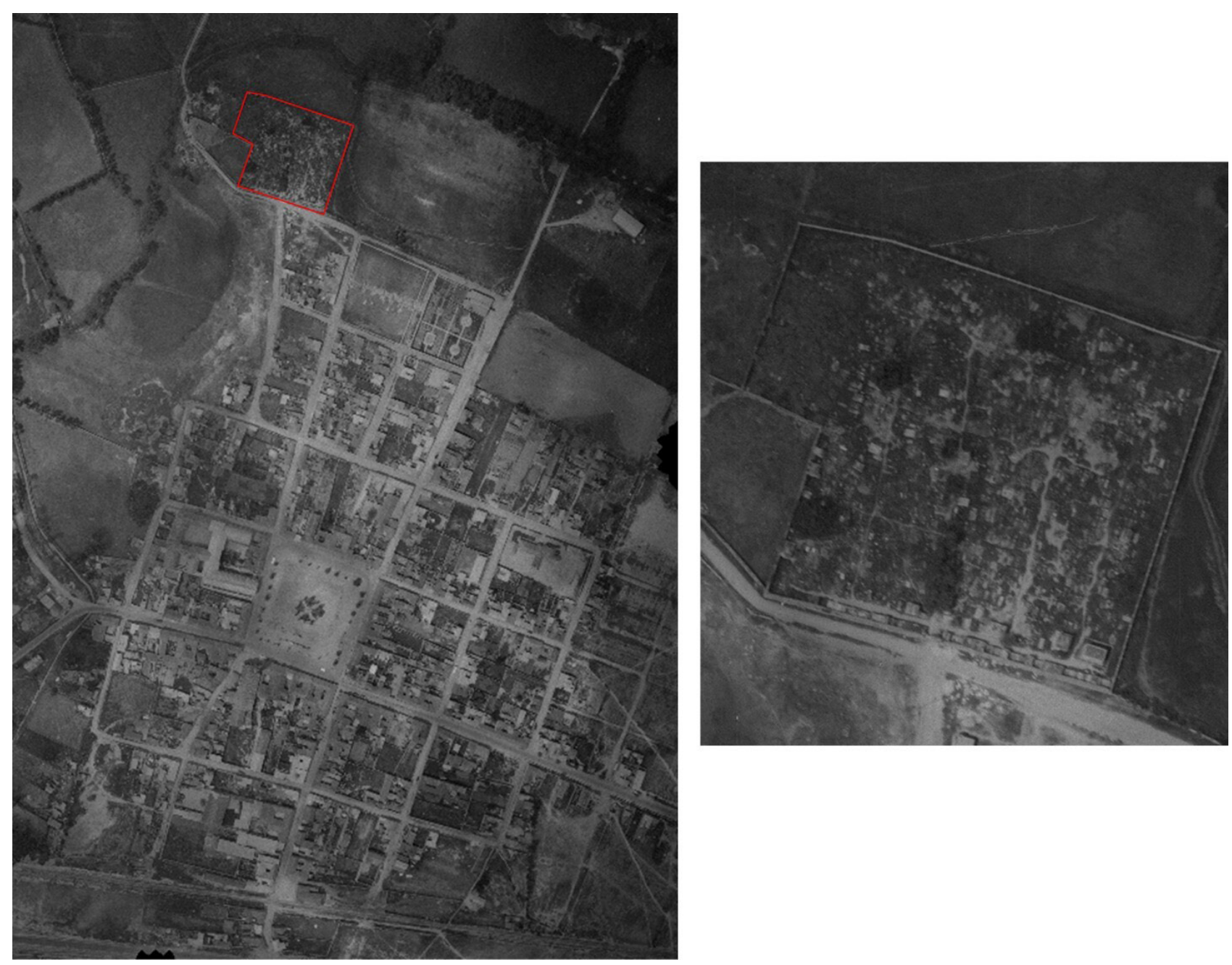

FIGURA 5. Aerofotografía del cementerio municipal de Soacha en 1958: se aprecia la distribución espacial de tumbas en mausoleos separados por senderos

FUENTE: Instituto Geográfico Agustín Codazzi (ICAC), vuelo A197. Modificado por el autor. 


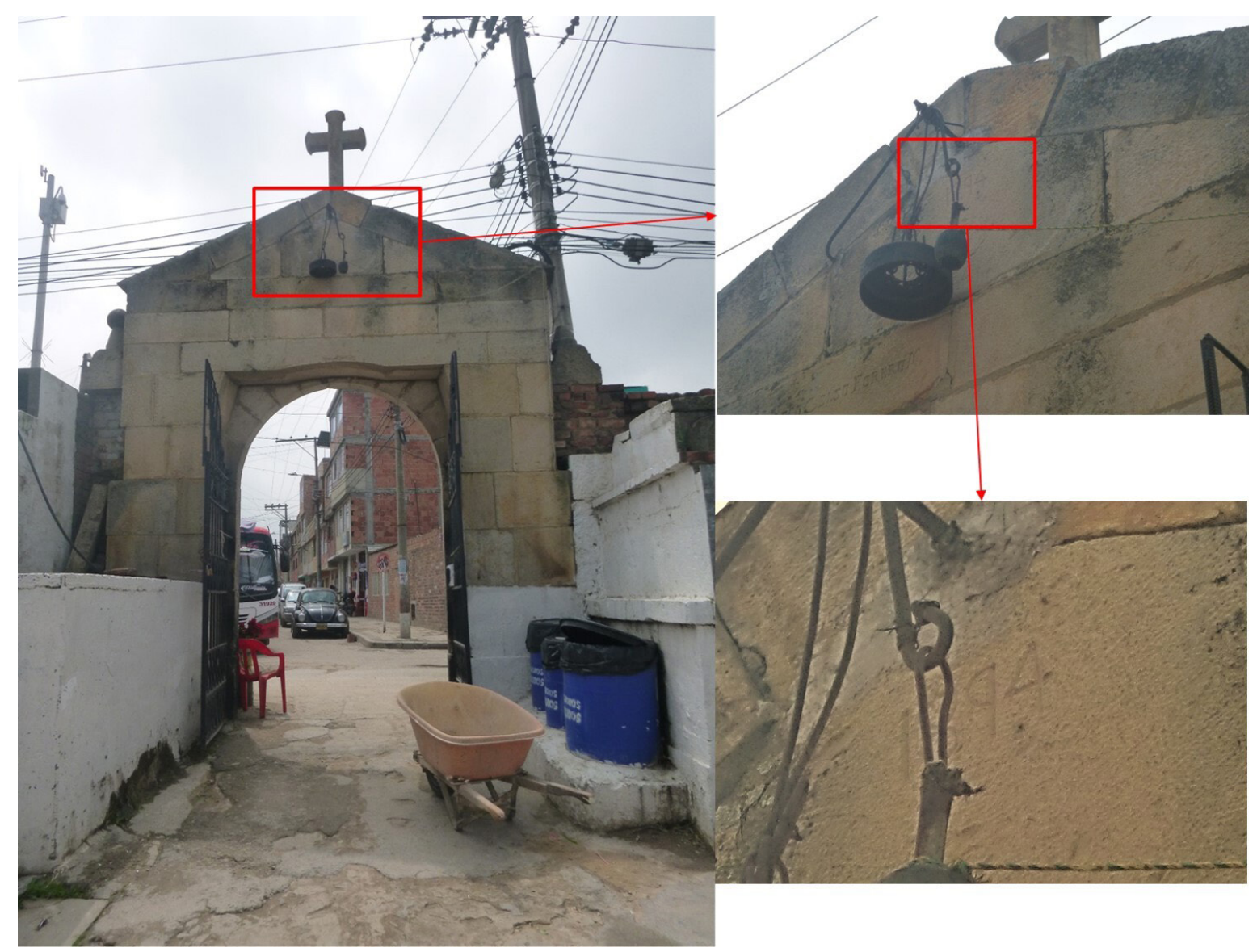

FIGURA 6. Vista interior de la portada del cementerio municipal de Soacha: en el detalle se observa la fecha de construcción y puesta en funcionamiento del camposanto en 1894 FUENTE: fotografía de Sebastián Rivas (2021).
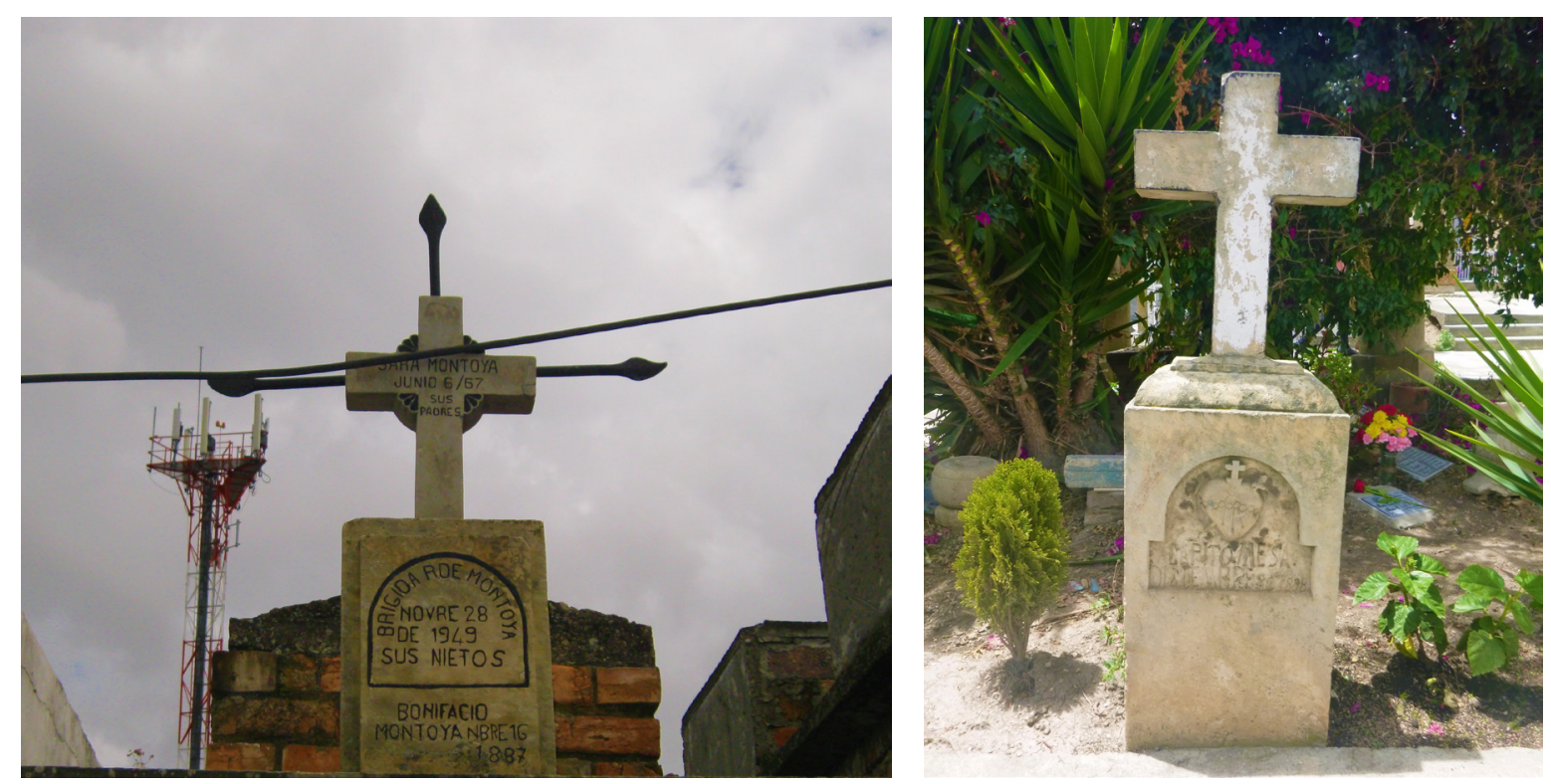

FIGURA 7. Lápidas asociadas a las primeras etapas de inhumación desarrolladas en el cementerio municipal de Soacha FUENTE: fotos de Sebastián Rivas (2020). 
Muchos de los documentos que pudieron aportar información relevante sobre la conformación del cementerio fueron destruidos o extraviados por cuenta de los administradores de la parroquia de San Bernardino de Soacha, tal y como lo expresa la administración actual del camposanto (Julián Mora, comunicación personal, 2016). Sin embargo, el hecho de la conformación tardía del cementerio puede indicar que solo hasta entonces la población de este municipio había aceptado por fin las inhumaciones en los camposantos y demuestra lo lento y gradual del proceso de cambio de las tradiciones funerarias, las cuales ya se habían arraigado en una población mayoritariamente indígena.

La portada del camposanto y las bóvedas de la entrada al parecer fueron construidas con los escombros de la capilla doctrinera de San Bernardino de Soacha, demolida a raíz del sismo de 1917 que afecto a la población. Si bien no existen grabados, pinturas o fotografias del cementerio que den cuenta de su aspecto durante su primera etapa de conformación, lo más probable es que se caracterizara por una estética similar a la del Cementerio Central de Bogotá, el cual se convirtió en el referente más claro de cómo debía lucir un cementerio.

Los ritos de enterramiento, el desarrollo del duelo, el culto a los muertos, la cremación y las nuevas propuestas de cementerios, en especial los jardines cementerios, han sido motivo de tensiones entre los usuarios y las instituciones públicas a través de políticas de salubridad. A partir de la puesta en rigor del Decreto 367 de 1995, en donde se establecieron medidas para mejorar las condiciones de funcionamiento de los cementerios en términos ambientales y administrativos, en este camposanto, como en muchos otros del territorio colombiano, se prohibió el desarrollo de inhumaciones bajo tierra, hecho que generó tensiones entre los usuarios y la administración de la necrópolis ya que, en muchos casos, no se podrían continuar desarrollando las prácticas funerarias como tradicionalmente se llevaban a cabo porque la cadaverina se convierte en un agente altamente contaminante dada su cercanía con el río Soacha, fuente hídrica que desemboca en el río Bogotá, pero que antes de llegar a este recorre un amplio sector urbano y varios potreros que surten de agua a pobladores, ganado y cultivos que no contaban con red de acueducto y alcantarillado.

Esta situación impulsó la construcción de bóvedas y mausoleos que fueron motivo de nuevas tensiones entre la administración y los usuarios, ya que se pretendía generar estándares constructivos tanto para los monumentos funerarios como para las lápidas. Para comprender estos hechos es necesario tener en cuenta que el entierro de un miembro de la comunidad genera para cualquier grupo social un impacto y una alteración en las relaciones sociales.

El duelo y las expresiones del mismo repercuten en las formas como se tramita o experimenta el dolor. Las formas de significar, de representar y, sobre todo, de recomponer las relaciones y la estructura social son motivo de tensiones entre individuos del mismo grupo social, entre los dolientes y las administraciones del cementerio o las instituciones religiosas.

El prohibir el uso de arreglos florares naturales, con el fin de darle cumplimiento a la Ley 715 de 2001, Decreto 313 de 2006, es uno de los que causan más tensiones entre los dolientes y las administraciones de los cementerios. Este hecho generó reacciones entre los usuarios y los vendedores de flores en contra de la administración, los cuales no solo hicieron caso omiso a la normatividad, sino que apelaban a sus creencias religiosas y su derecho al trabajo para derogar dicha normativa.

Un nuevo punto de tensiones experimentadas en la necrópolis se generó como consecuencia de las transformaciones que ha experimentado el cementerio a lo largo de los años, pero, sobre todo en los últimos tiempos, se han ido identificando cambios en la estética, en la forma en que se construyen y adornan las tumbas. El art deco visible en mausoleos y tumbas de 
finales del siglo XIX y comienzos del xx ha sido reemplazado por la estandarización que ofrecen las nuevas tecnologías de producción en serie de lápidas, con el fin de otorgar uniformidad estética al cementerio.

Pese a estos intentos de estandarización en las lápidas, amparados en normativas como las enunciadas, los nuevos usuarios del cementerio se resisten a caer en la trampa de la homogenización y ornamentan de las tumbas de sus difuntos con elementos únicos que les permiten recobrar la identidad del muerto (Figura 8). En este escenario entran en tensión la religiosidad y el arte popular, y se ubican en un mismo nivel las imágenes de divinidades con representaciones mundanas de personajes caricaturescos, insignias de equipos de futbol y sus jugadores, entre otros.

Este dialogo de imágenes ha sido interpretado por algunos usuarios y por la comunidad religiosa como un sacrilegio. Sin embargo, para quienes las usan y defienden se transforman en un vehículo de comunicación muy potente con el difunto y posibilitan la tan anhelada recomposición de la estructura social desestabilizada por la muerte.

El arte popular ha encontrado una nueva forma de expresión en este camposanto: la miniaturización de figuras que adornan las lápidas de mausoleos o bóvedas, las cuales se han convertido en un elemento único en las formas de ornamentación de las tumbas de este cementerio. Estos elementos votivos, además de adquirir un significado simbólico al ser dispuestos como ofrendas funerarias, en algunos casos tratan de otorgarle a los difuntos atributos de su identidad.

La práctica de la magia al interior del camposanto hace parte de la idiosincrasia de las poblaciones colombianas por cuenta de trayectorias históricas que implicaron el desarrollo de un sincretismo religioso que fusionó las tradiciones indígenas, africanas y europeas (Villa Posse, 1993). El culto a las ánimas benditas del purgatorio es una práctica de comunicación con los muertos que se ha mantenido vigente durante décadas por parte de los usuarios de este camposanto, en donde, además del desarrollo de oraciones por el descanso del alma del fallecido, se lleva a cabo una negociación con el muerto a fin de obtener un favor en especial. Se cree que las almas de los muertos tienen poderes y que entre ellas las más poderosas son las de los NN o de aquellos muertos cuyas tumbas han caído en el abandono de sus familiares.

Los NN, al perder su identidad y no gozar de los rituales funerarios ortodoxos, entran en un estado liminal que, de acuerdo con las creencias populares, les otorga poderes que les permiten transitar entre el mundo de los vivos y el de los muertos. Sin embargo, su anhelo es poder continuar el tránsito hacia el más allá y por ello realizan negociaciones con los vivos, con el fin de recibir ofrendas y oraciones que les permitan salir de la liminalidad.

El poder de eficacia simbólica, tal como la describe Lévi-Strauss (1995), cobra una gran fuerza entre los usuarios de este camposanto, ya que la seguridad que experimentan las personas que desarrollan estos actos comunicativos y negociaciones frente a las ánimas les obliga a cumplir el pacto, so pena de no ver materializada su petición y enfrentarse a un castigo o tormento por parte de los espíritus de aquellos sepultados en las bóvedas para NN.

Realizar actos de comunicación, ofrendas y peticiones con muertos NN ha sido una práctica ampliamente difundida a lo largo y ancho del territorio colombiano (Villa Posse, 1993), a tal punto que hace parte de la idiosincrasia de sus habitantes. La creencia en el poder de las ánimas benditas del purgatorio hace parte de la tradición católica, en la cual el cuerpo muerto goza de un valor simbólico muy alto. El dogma católico le otorga reconocimiento y poder a los espíritus de los difuntos, el cual se mezcló con las creencias de los pueblos indígenas del Nuevo Mundo, en donde se observa que la relación con los antepasados, sus cuerpos y energías hacía parte de la vida cotidiana (Figura 9). 

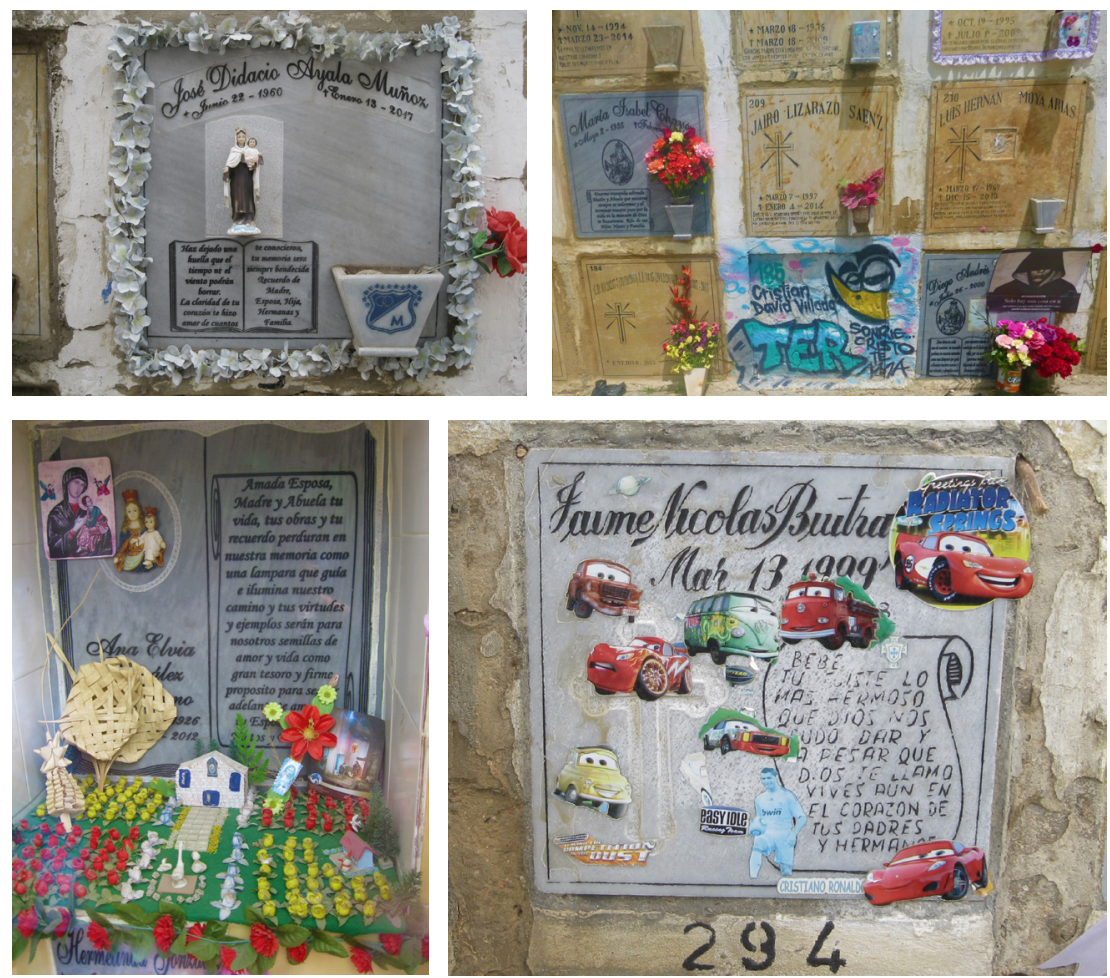

FIGURA 8. Decoración de lápidas observadas al interior del cementerio municipal de Soacha que motivan tensiones entre lo sagrado y lo profano FUENTE: fotos de Sebastián Rivas (2020).

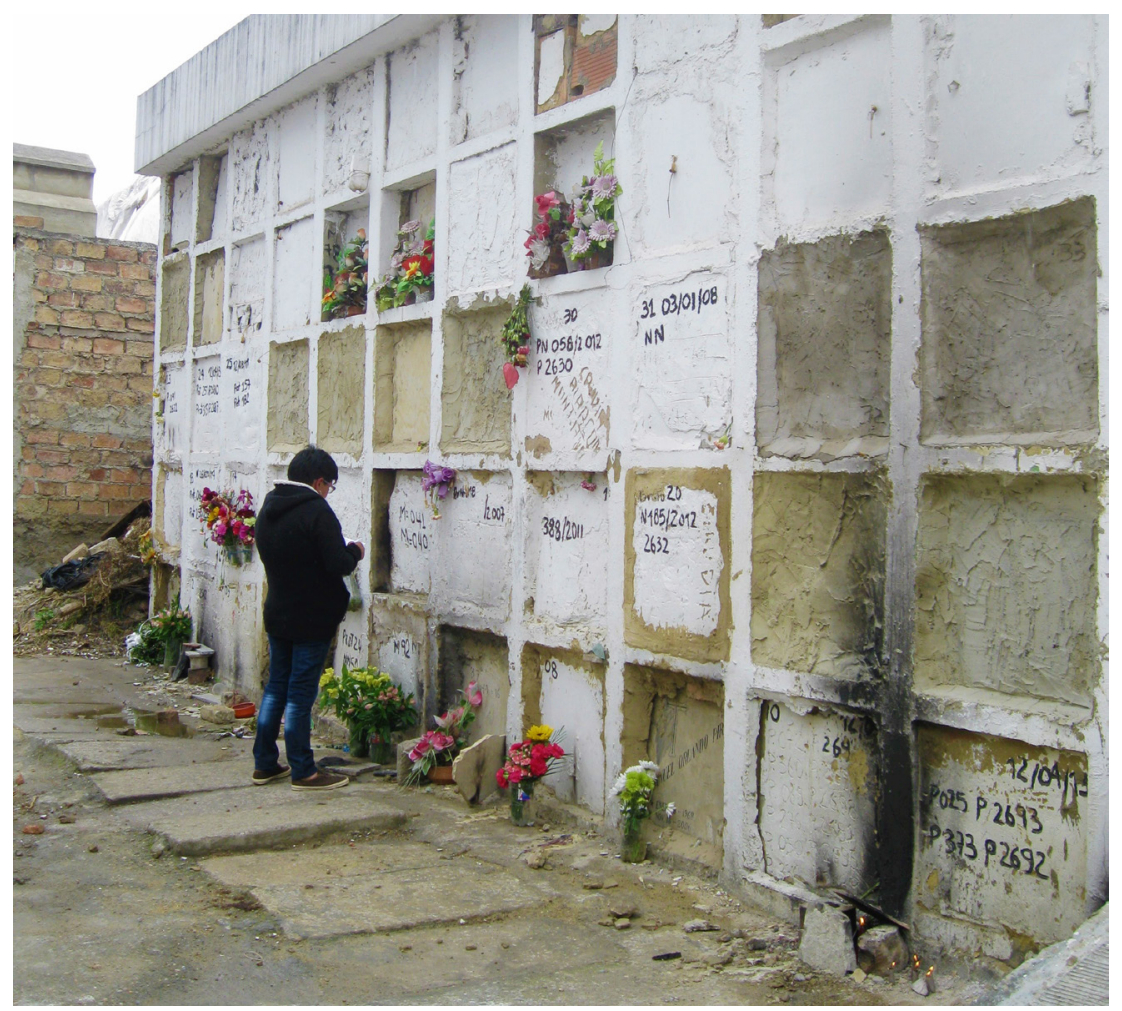

FIGURA 9. Ejemplo del culto a las ánimas benditas del purgatorio desarrollado en las bóvedas reservadas para sepultar a los NN en el cementerio municipal de Soacha FUENTE: foto de Diana Calderón (2018). 
La brujería hace parte de un conjunto de prácticas inspiradas en rituales religiosos y forma parte de una tradición de larga duración que se ha incorporado en la vida de la sociedad y encuentra en los cementerios el escenario predilecto para ser oficiada. En la brujería se invocan conjuros, rezos o "amarres" de recaen sobre una persona con el fin de hacerle mal (Figura 10). El "yelo", los amarres y la víctima se constituyen en los elementos básicos para que los hechizos surtan efecto (Suárez Guava, 2009).

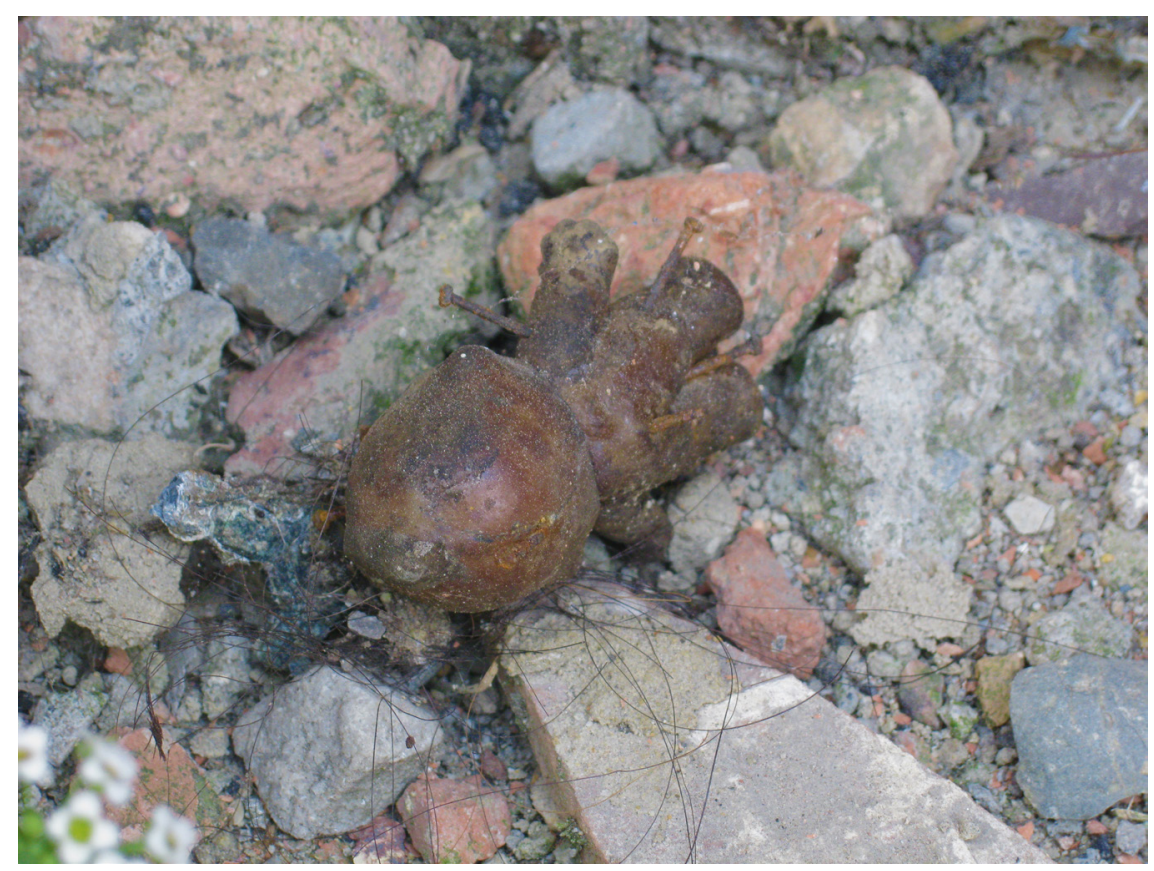

FIGURA 10. Muñeco con alfileres y cabello humano usado para el desarrollo de actos de magia en uno de los sectores del cementerio municipal de Soacha FUENTE: foto de Diana Calderón (2018).

\section{Conclusiones}

Los cementerios son espacios de negociación (Ferro, 1999) en donde lo tradicional u oficial se enfrenta con lo popular. Las instituciones religiosas (en especial aquellas de fe católica), a través de la institucionalización del ritual funerario, establecieron una serie de pasos que dan un orden y un sentido a la ceremonia, permiten cerrar el ciclo de la vida y preparar al difunto para el juicio final. Así mismo, los dolientes en muchos casos enriquecen las manifestaciones religiosas con sus formas particulares de expresar el duelo, vinculan lo sagrado con lo profano,

7 Para profundizar sobre este concepto se recomienda al lector remitirse al artículo "Lluvia de flores, cosecha de huesos. Guacas, brujería e intercambio con los muertos en la tragedia de Armero" (Suárez Guava, 2009). lo religioso con lo secular y generan un dinamismo en la práctica religiosa que permite la supervivencia del lugar al ser transmitidas de generación en generación. Esto motiva tensiones, ya que las instituciones religiosas ven con recelo la pérdida del control absoluto en el rito de paso.

El cementerio municipal de Soacha ha sido objeto y escenario de tensiones en tiempos recientes entre la Iglesia católica y los pobladores de este municipio. Los nuevos fenómenos de poblamiento y migración al municipio han generado dinámicas en la expresión de las prácticas religiosas que chocan con las formas de expresión tradicional, los mismos que acarrean problemas a la hora de generar valoraciones patrimoniales. 
El valor histórico, estético y simbólico del cementerio municipal de Soacha es incuestionable, ya que este camposanto se convierte en testigo privilegiado y documento a cielo abierto de su propia historia. Contiene en su interior información muy valiosa para la comprensión de los procesos sociales y culturales de Soacha desde finales del siglo XIX al XXI. Este cementerio invisibilizado y estigmatizado, arrinconado por el crecimiento urbanístico desmedido, es un pequeño reflejo de lo que hoy es Soacha.

En el mundo occidental los cementerios fueron una solución sanitaria y materializaron una política pública que cruzo fronteras con el ánimo a consolidarse a perpetuidad. Sin embargo, los cementerios, como la mayoría de las creaciones del hombre, son efímeros, y en particular estos se exponen a los cambios que se generen a nivel ideológico y religioso en el seno de la sociedad. Los cementerios sintetizan en su arquitectura, su simbolismo y su distribución espacial las costumbres y las manifestaciones funerarias de las poblaciones que los crearon y que han formado un renglón importante a nivel cultural en las sociedades occidentales. Su evolución y sus trayectorias se pueden relacionar con las poblaciones de diferentes épocas, por lo cual estos lugares no solo son idealizados, construidos y percibidos con el fin de rendirle culto a los muertos, conformando así un espacio cargado de simbolismo: fueron pensados para llevar a cabo rituales religiosos que permiten restaurar la estructura social en todos los niveles, ya que en ellos se expresan múltiples relaciones sociales y permiten darle continuidad a la vida al ser truncada por la muerte, hecho que obliga a reestructurarlos con el fin de mantener el orden social.

Los cementerios contribuyen a reactivar procesos de memoria ${ }^{8}$ e identidad colectiva. El cementerio, analizado como territorio de la memoria, está inserto en el acto de recordar, el cual se desarrolla de manera individual, pero, a su vez, se inscribe en procesos

8 Se alude nuevamente al concepto de memoria de Ricoeur (cf. nota al pie 4 de este artículo). colectivos (Santos Moreno, 2013). En este orden de ideas, el cementerio municipal de Soacha puede ser interpretado como un "lugar de la memoria" (Nora, 1996), como espacio de rememoración con un valor simbólico particular y con fuertes recreaciones del contexto sociopolítico (Moranense, 2009).

\section{Referencias}

Archivo General de la Nación (AGN). Mapa del siglo Xvi en el que se aprecia la ubicación del pueblo de Soacha. Sección Mapas y Planos, Mapoteca n 4, ref. 443A. AGN.SMP.4.

Ballart, J. (1997). El patrimonio histórico y arqueológico: valor y uso. Editorial Ariel s.A.

Blanco, C. (2010). Hipótesis principales sobre el origen de la idea de resurrección de los muertos en el judaismo. Estudios Bíblicos, 68(4), 429-472.

Boada, A. M. (2000). Variavilidad mortuoria y organización social muisca en el sur de la Sabana de Bogotá. En: B. Enciso \& M. Therrien (ed.), Sociedades complejas en la Sabana de Bogotá. Siglos VIII al XVI d.C. (pp. 21-58). Instituto Colombiano de Antropología e Historia.

Botiva, A. (1989). La altiplanicie cundiboyacense. En: A. Botiva, L. Herrera, A. M. Groot \& S. Mora (ed.), Colombia prehispánica: regiones arqueológicas (pp. 77-117). Instituto Colombiano de Antropología e Historia; Colcultura.

Calderón, D. \& Rivas, S. (2017, abril 23). Espacios de vida y muerte. Contextos domésticos y funerarios en el sitio arqueológico Nueva Esperanza. Conferencia dictada en el ciclo "Transformaciones sociales de los muiscas" del Museo del Oro del Banco de la Republica.

Calderón, D. I., Marulanda, C., Mendoza, L., Moreno, O., Rivas, S., \& Santa, T. (2019). Bioantropología y contextos funerarios. En: T. Santa, J. C. Vargas \& P. Argüello (eds.), Arqueología de Nueva Esperanza (pp. 83100). CODENSA S.A. ESP - UPTC.

Cancino, J. A. (1940). Monografia del municipio de Soacha. Editorial Santafé.

Cárdenas Arroyo, F. (2002). Datos sobre la alimentacion prehispanica en la Sabana de Bogotá, Colombia. Informes Arqueológicos del Instituto Colombiano de Antropología e Historia, $\mathrm{n}^{\circ} 3$.

Colón, L. C. (2004). Espacio para los muertos y ritos para la memoria. En: Las ciudades y los muertos (pp. 31-50). 
Instituto Distrital de Cultura y Turismo; Alcaldía de Bogotá; Corporación La Candelaria; Museo de Bogotá.

Correal, G. \& Van der Hammen, T. (1977). Investigaciones arqueológicas en los abrigos rocosos del Tequendama. Biblioteca Banco Popular.

Correal Urrego, G. (1979). Investigaciones arqueológicas en los abrigos rocosos de Nemocón y Sueva. Fundación de Investigaciones Arqueológicas Nacionales; Banco de la República.

Correal Urrego, G. (1990). Aguazuque, evidencia de cazadores, recolectores y plantadores en la altiplanicie de la cordillera Oriental. Fundación de Investigaciones Arqueológicas Nacionales; Banco de la República.

Correal Urrego, G. (2001). Patrones mortuorios en cazadores recolectores del Pleistoceno y Holoceno en Colombia. Chungará (Arica), 33(1), 37-42. https://doi. org/10.4067/S0717-73562001000100006

Escovar, A. (2002). El Cementerio Central y los primeros cementerios católicos. Revista Credencial Historia, 15, $13-15$.

Escovar, A. \& Mariño von Hildebrand, M. (2007). Guia del Cementerio Central de Bogotá: elipse central. Alcaldía Mayor de Bogotá; Corporacion la Candelaria.

Ferro, G. (1999). Nuevas metodologías en etnografías de lo sagrado: la geografía de lo sagrado en Colombia. Los santuarios, un escenario para la batalla, la circulación y la apropiación de signos. En: Memorias II Seminario de Antropología de la Religión (pp. 232-250). Pontificia Universidad Javeriana.

Gamboa, J. A. (2013). El cacicazgo muisca en los años posteriores a la Conquista: del psihipqua al cacique colonial (1537-1575) ( $2^{\text {a }}$ ed). Colección Espiral, ICANH.

García Canclini, N. (1990). Culturas híbridas: estrategias para entrar y salir de la modernidad. Grijalbo.

González, J. (2016). Informe Final del Proyecto de Rescate Arqueológico Subestación Nueva Esperanza, Soacha, Cundinamarca. [AIA 2874]. Instituto Colombiano de Antropología e Historia.

Groot, A. M. (1992). Checua: una secuencia cultural entre 8500 y 3000 años antes del presente (municipio de Nemocón). Banco de la Republica.

Hurt, W., Van der Hammen, T., \& Correal Urrego, G. (1977). The El Abra rocksbelters, Sabana de Bogotá (Colombia, South America). Occasional Papers and $\mathrm{Mo}^{-}$ nographs, $\mathrm{n}^{\circ} 2$.
Jiménez de Quesada, G. (S. f.). Epitome de la Conquista del Nuevo Reino de Granada (D. Ramos, ed.).

Lamilla Guerrero, E. (2011). El Cementerio Central de Neiva (Huila): escenario de activación, reinterpretación y disputa de múltiples memorias. Universitas $H u$ manistica, 72, 189-210.

Langebaek, C., Bernal, M., Aristizabal, L., Corcione, M., Rojas, C., \& Santa, T. (2011). Condiciones de vida y jerarquías sociales en el norte de Surámerica: el caso de la población muisca en Tibanica, Soacha. Indiana, $28,15-34$.

Langebaek, C. H. (Comp.) (2012). Vivir y morir en Tibanica: reflexiones sobre el poder político en una comunidad muisca de la Sabana de Bogotá. [Investigación sin editar].

Langebaek, G. H., Jaramillo, A., Aristizabal, L., Arevalo, M. B., Corcione, M. A., Mendoza, L. F., Perez, L., Rodriguez, F., \& Zorro, C. (2015). Vivir y morir en Tibanica: Reflexiones sobre el poder y el espacio en una aldea muisca tardia de la sabana de Bogota. Revista Colombiana de Antropología, 51(2), 173-207.

Leguizamón, L. P. (2016). Informe Arqueológico n 9. Explorando la noción de casa en los contextos domésticos y funerarios de la Sabana de Bogotá, entre los siglos VIII y XIII d. C. Instituto Colombiano de Antropología e Historia.

Lévi-Strauss, C. (1995). Antropología estructural (2ª reimp.). Ediciones Paidós.

Losonczy, A. (2001). Santificación popular de los muertos en cementerios urbanos colombianos. Revista Colombiana de Antropología, 37, 6-23.

Moranense, L. (2009). Baldosas por la memoria. Una experiencia de autogestión y participación vecinal. En: $X$ Encuentro Iberoamericano de Valoración y Gestión de Cementerios Patrimoniales: "memoria, memoriales y memorables" (pp. 1-9). Medellín.

Nora, P. (1996). The Construction of the Past French. Columbia University Press.

Pinto, M. (2003). Galindo, un sitio a cielo abierto de cazadores-recolectores en la Sabana de Bogotá (Colombia). Fundación de Investigaciones Arqueológicas Nacionales; Banco de la República.

Reichel-Dolmatoff, G. (1990). Orfebreria y chamanismo. Un estudio iconografico del Museo del Oro. Editorial Colina.

Riaño, G. (2016). La transformacion del paisaje urbano en Usaquén - de pueblo de indios a localidad de Bogotá. Pontificia Universidad Javeriana.

Rivas, S. (2020). Implementación del Plan de Manejo Arqueológico para el rescate y monitoreo del sitio subestación Nueva Esperanza 
en el marco del proyecto Segundo Refuerzo de Red del Área Oriental Linea de Transmisión La Virginia Nueva Esperanza a 500 kV. Convocatoria UPM. [Manuscrito sin publicar].

Rivera, J. (2006). Sepulturas abiertas en la Nueva Granada. Reflexiones sobre una arqueología histórica de la muerte. En: P. P. Funari \& F. Brittez (ed.), Arqueología histórica en América Latina, temas y discusiones recientes (pp. 139-162). Ediciones Suárez.

Rodríguez, A. L. (1999). Cofradías, capellanías, epidemias y funerales. Una mirada al tejido social de la independencia. Banco de la Republica; El Áncora Editores.

Rodríguez, F. (2017). Del poblamiento prehispánico al modelo territorial colonial en el municipio de Soacha, Cundinamarca: reflexión geohistórica de su configuración socioespacial. Perspectiva Geográfica, 22(1), 69-88. https://doi.org/10.19053/01233769.6112
Romano, F. et al. (ed. y comp.) (2016). Estudio arqueológico y de intervención de los bienes culturales para realizar el rescate en el sitio de terreno donde se ubicarán las futuras bahias y banco de reactores Nueva Esperanza EEB. [Informe Final, Instituto Colombiano de Antropología e Historia].

Santos Moreno, J. (2013). Cementerio de Pueblo Viejo (Guatavita): anclaje para la memoria y la historia del valle de Tominé. Pontificia Universidad Javeriana.

Suárez Guava, L. A. (2009). Lluvia de flores, cosecha de huesos. Guacas, brujería e intercambio con los muertos en la tragedia de Armero. Maguaré, 23, 371-416.

Uvietta, A. (2015). Patrimonio cultural del cementerio de Magdalena. Universidad Nacional de la Plata.

Villa Posse, E. (1993). Muerte, cultos y cementerios. Disloque Editores. 